\title{
KAJIAN KONSEP ARSITEKTUR MODULAR PADA RUMAH SUSUN ITB JATINANGOR
}

\author{
Shely Pratiwi Sanjaya Putri*1, Ari Widyati Purwantiasning2 \\ Teknik Arsitektur Universitas Muhammadiyah Jakarta ${ }^{1,2}$ \\ e-mail:*12017460054@ftumj.ac.id,2Ari.widyati@umj.ac.id
}

\begin{abstract}
Abstrak_ Di kota besar dan metro pengembangan hunian vertikal sudah menjadi kebutuhan yang sangat mendesak, permasalahan berupa ketersediaan lahan merupakan salah satu faktor pendorong pemangku kepentingan untuk segera menyelesaikan permasalahan tersebut. Kontruksi yang digunakan pun bermacammacam dan terus berkembang setiap tahunnya. Pada masa setelah perang dunia kedua konsep hunian dengan modular mulai popular, dan konsep tersebut memiliki banyak keunggulan sehingga pada masa sekarang sudah mulai digunakan dan dikembangkan. Secara general konsep Arsitektur Modular dapat didefinisikan berupa objek rancangan berdasarkan modul tertentu, dengan bentuk yang sama dan diulang secara berulang-ulang. Le Corbusier juga berpendapat pada "Teori Modular" bahwa melihat Modular bukan hanya sebagai angka yang mengadopsi harmoni, namun juga sebagai alat pengukur yang dapat menghitung jarak, permukaan, dan volume. Penelitian ini menggunakan metode deskriptif kualitatif, dengan tujuan untuk mengetahui dan memahami Penerapan Konsep Arsitektur Modular pada Rumah Susun ITB Jatinangor. Kesimpulan yang didapat ialah Rumah Susun ini telah menerapkan dan sesuai dengan prinsip serta syarat modular dari Teori Modular Le Corbusier dan Teori Ryan E. Meskipun pada sistem struktur, bangunan ini secara keseluruhan belum menggunakan komponen prefabrikasi, namun secara garis besar 95\% bangunan ini telah menggunakan modul prefabrikasi antara lain komponen kolom, balok, plat, dinding, tangga dan tiang pancang. Sehingga bangunan ini dapat dikatakan sebagai bangunan modular. Serta komponen bangunan yang tidak dalam komponen modular ialah komponen pada struktur bawah yaitu pada pilecap dan pada dinding pada area tangga, yang menggunakan metode konvensional pada saat pembangunan terjadi.
\end{abstract}

Kata kunci: Hunian Vertikal; Modular; Prefabrikasi.

\begin{abstract}
In large cities and metro vertical residential development has become a very urgent need. The problem of land availability is one of the driving factors for stakeholders to solve the problem immediately. The construction used is various and continues to grow every year. In the post-world war second world, the concept of modular housing began to be popular, and the concept has many advantages, so it has started to be used and developed in the present. In general, the concept of Modular Architecture can be defined as a design object based on a specific module, with the same shape and repeated repeatedly. Le Corbusier also argues in the "Modular Theory" that it sees Modular not only as a number that adopts harmony but also as a gauge that can calculate distance, surface, and volume. This research uses a qualitative descriptive method to know and understand the Application of Modular Architecture concepts in ITB Jatinangor Flats. The conclusion obtained is that this flat has been applied and by the modular principles and requirements of The Le Corbusier Modular Theory and Ryan E Theory. Although in the structure system, the building as a whole has not used prefabricated components, but in general, 95\% of the building has used prefabricated modules, including column components, beams, plates, walls, stairs, and stakes. So this building can be said to be a modular building, and building components that are not in modular components are elements on the lower structure on the pile cap and on the wall in the stairwell area, which uses conventional methods at the time of construction.
\end{abstract}

Keywords: Vertical Housing; Module; Prefabricated.

\footnotetext{
${ }^{1}$ Teknik Arsitektur Universitas Muhammadiyah Jakarta

${ }^{2}$ Teknik Arsitektur Universitas Muhammadiyah Jakarta
} 


\section{PENDAHULUAN}

Penggunaan lahan yang terus meningkat di kota-kota besar, kelak akan menimbulkan masalah keterbatasan lahan di masa yang akan datang. Setiap tahun tingkat kelahiran dan migrasi penduduk dari berbagai daerah semakin bertambah menurut (Muryono 2020). Pada kenyataanmya bahwa lahan di perkotaan semakin terbatas dan nilai lahan yang semakin meningkat tiap tahunnya, dan akan menimbulkan sebuah pemukiman yang padat di kawasankawasan yang dianggap strategis seperti kawasan industri, pusat-pusat kota dan perguruan tinggi(Satria and Sunaryo 2017). Dalam merespon permasalahan ini alternatif yang dianggap paling sesuai untuk kondisi tersebut yaitu pembangunan secara vertikal berupa hunian vertikal, Di Indonesia hunian vertikal terbagi menjadi 3 jenis (Purwanto 2016) yaitu : Rumah Susun Sederhana (Rusuna), Rumah Susun Menengah (Apartemen) dan Rumah Susun Mewah (Condominium).

Secara general konsep Arsitektur Modular dapat didefinisikan berupa objek rancangan berdasarkan modul tertentu, dengan bentuk yang sama dan diulang secara berulang-ulang. Modular dalam desain itu merupakan pendekatan desain yang membagi sistem menjadi bagianbagian yang lebih kecil, yang disebut "Modul". Le Corbusier juga berpendapat pada "Teori Modular" bahwa melihat Modular bukan hanya sebagai angka, namun juga sebagai alat pengukur yang dapat menghitung jarak, permukaan, dan volume (Monindra 2016). Skala manusia yang dijelaskan pada teori dari Le Corbusier ialah memiliki ukuran setinggi dari tubuh manusia dengan lengan diangkat keatas, dan menghasilkan sebuah ukuran setinggi $226 \mathrm{~cm}$ atau setara dengan 2,3m. Analogi modular ialah sesuatu keberhasilan sebuah desain arsitektur dalam konsep modular yang mampu menghasilkan varian desain dengan jumlah komponen terbatas. Karakteristik penerapan koordinasi modular : dapat diproduksi secara industrial, mampu mengurangi jumlah tenaga kerja professional, merupakan desain yang lebih modern dengan memanfaatkan CAD (design) dan CAM (manufacturing) serta sistem quality control terjamin (Astuti et al. 2016).

Rata-rata sebuah modul telah disusun (tembok, atap, lantai) dan telah diselesaikan 60\%-90\% di luar site yaitu di dalam pabrik, kemudian ditransportasikan dan dirakit di dalam site sebuah proyek pembangunan (Sanjaya and Tobing 2019). Konstruksi modular sangat berkaitan dengan prefabrikasi, dan banyak orang menjadikan sistem modular sebagai bentuk dari prefabrikasi dari segi istilah. Dengan sistem fabrikasi dalam memproduksi modul tersebut, dinilai mampu menekan waktu pelaksanaan pembangunann (Prihatanti and Faqih 2016). Pada umunya konstruksi pada konsep arsitektur modular menggunakan komponen precast atau beton pracetak. Komponen precast identik dengan bentuk dan ukuran yang berulang sesuai dengan modul material yang telah ditentukan menurut (Subekti, Alencia, and Rafika 2016). Namun ada juga struktur modular lainnya seperti: struktur precast, baja/hybrid, MET (mass Engineered timber), PPVC (Prefinished Volumetric Construction) dan struktur peti kemas (container). Ketentuan modul tersebut juga akan berpengaruh pada material lainnya yang seperti material plafond, kramik dan bukaan berupa jendela, pintu dan ventilasi.

Sampai saat ini belum tercacat infomasi yang jelas mengenai pengaplikasian sistem modular di Indonesia, baik pada hunian secara veritikal maupun horizontal. Sudah saatnya dikaji lebih lanjut terhadap efisiensi waktu (efektifitas), efisiensi ekonomi (pertimbangan ekonomi) serta potensi pengembangan Konsep Arsitektur Modular pada bangunan Hunia Vertikal di Indonesia. กั Tujuan dari penelitian ini ialah mengkaji lebih lanjut mengenai prinsip dan syarat dari konsep 
Arsitektur modular secara general dan penerapan yang terjadi apabila konsep tersebut diaplikasikan pada Hunian Vertikal bertingkat sedang .

\section{METODE}

Metode penelitian menggunakan deskriptif kualitatif, yaitu mendeskripsikan dan menjelaskan setiap pembahasan. Studi kasus dari penelitian ini ialah Rumah Susun ITB Jatinangor yang berlokasi di Desa Sayang, Jatinangor, Kabupaten Sumedang, Jawa Barat. Pengambilan data pada studi kasus ini dilakukan melalui studi literatur/pustaka. Waktu penelitian dilakukan dari bulan September hingga desember 2020. Proses analisis dan pembahasan pada penelitian Kajian Arsitektur Modular Pada Rumah Susun ITB Jatinangor, dikaji dan diteliti dengan didasari oleh teori Modular Le Corbusier tentang sistem modular dan teori Ryan E. Smith tentang arsitektur prefabrikasi.

\section{HASIL DAN PEMBAHASAN}

Kampus ITB Jatinangor, bangunan Asrama Mahasiwa ITB yang terdiri dari 5 (lima) lantai yang difungsikan sebagai asrama mahasiswa ITB Jatinangor. Rumah susun ini dibangun dengan konsep awal sebagai rumah susun modular pertama di Indonesia yang dibangun oleh PU. Rumah susun yang dirancang memiliki luas per unit seluas $24 \mathrm{~m} 2$ (T24) dengan jumlah target penghuni sebanyak 3-4 orang/unit. Luas lantai dasar rumah susun ini sebesar $499.23 \mathrm{~m} 2$.

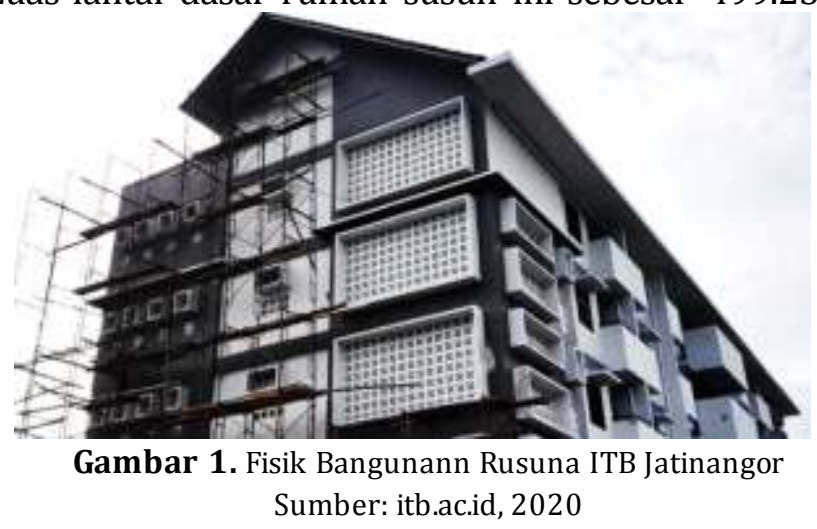

\section{A. Analisis Sistem Modular}

Modular menurut Teori Le Corbusier (Mameli 2016), ialah : Modular sesuai dengan skala manusia, skala manusia yang dijelaskan ialah memiliki ukuran setinggi dari tubuh manusia dengan lengan diangkat keatas, dan menghasilkan sebuah ukuran setinggi $226 \mathrm{~cm}$ atau setara dengan 2,3m. Sebuah bangunann dapat dilihat sistem modularnya melalui:

1. Modul Grid Arah Horizontal, untuk mengetahui kesesuaian luas ruangan terhadap kebutuhan penghuni didalamnya.

2. Modul Grid Arah Vertikal, untuk mengetahui tinggi dalam ruangan dengan menjadikan skala manusia sebagai acuan minimal.

\section{a. Kongfigurasi Grid Modul Arah Horizontal}

Kongfigurasi pada modul Rumah susun ITB Jatinangor ini dibentuk dengan menata deret tiap unit kearah memanjang yang dihubungkan oleh sebuah koridor (double Loaded) pada sisi tengah bangunan yang digunakan sebagai jalur transportasi horizontal serta sarana tangga yang terletak pada sisi kanan kiri bangunan. Grid modul pada Rumah Susun ini berbentuk Grid Bujursangkar (persegi) yang merupakan bentuk standar pada sebuah bangunan, karena 
kesamaan demensi dan sifat semetris dua arah, grid bujur sangkar pada prinsipnya, tak berjenjang dan tak berarah. Hal tersebut sesuai dengan prinsip teori modular dari Le Corbusier. Dimensi modul 4,3m x 4,3m dan Panjang rusun ditentukan oleh kelipatan dari modul ruang, sesuai unit yang dibangun.

Komponen modul pada grid horizontal memiliki komponen yang sama, terbukti dari ukuran ruangan yang seragam, tidak memiliki variasi yang mencolok. Dapat disimpulkan secara keseluruhan komponen yang digunakan pada rumah susun ini sama, yaitu modular Precast (beton pracetak) dari modul kolom, blok, dinding, plat dan tangga.

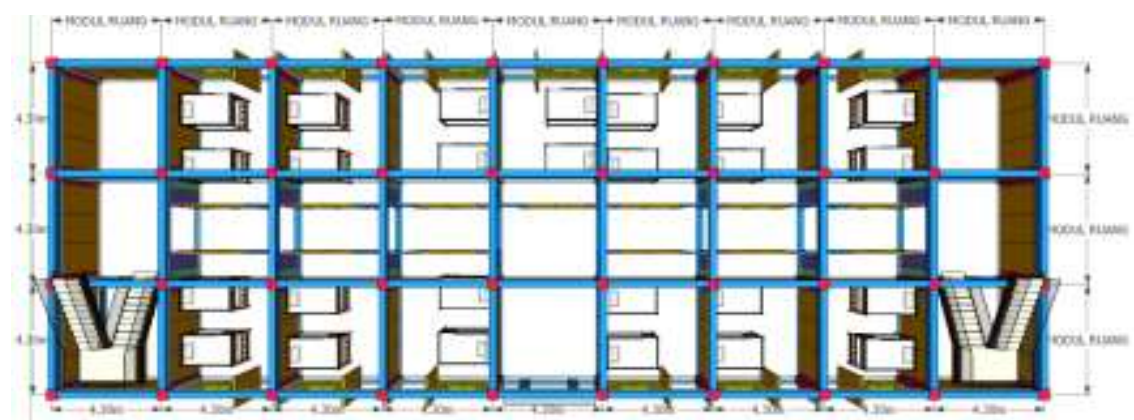

Gambar 2. Grid Modular Arah Horizontal Tipe Double Loaded Rusuna ITB Sumber: Peneliti, 2020

Standar ukuran ruang tidur menurut Data arsitek ialah $10 \mathrm{~m}^{2}$ untuk 2 orang dengan 2 ranjang tidur (tanpa kamar mandi). Grid Horizontal yang dihasilkan pada susunan modul ruang Rumah Susun ITB ini sebesar $18,5 \mathrm{~m}^{2}$, namun pada penyusunan tiap unit, menggunakan ukuran 1 modul ruang $+1 / 4$ modul ruang, sehingga total yang dihasilkan seluas $24 \mathrm{~m}^{2} /$ unit, dengan kapasitas yang telah ditentukan sebanyak 4 penghuni. Jika ditinjau dengan standar ruang menurut data arsitek, luas modul ruang pada Rumah Susun ITB ini telah sesuai, karena setiap unit menyediakan ruangan seluas $24 \mathrm{~m}^{2}$ (tanpa kamar mandi) untuk 4 penghuni dengan pengunaan furniture berupa 2 kasur tingkat, 4 meja belajar dan 4 lemari pakaian kecil.

\section{Kongfigurasi Grid Modul Arah Vertikal}

Pada kongfiguras grid arah vertikal dapat diketahui, apakah modul yang tercipta pada Rumah susun ini sesuai dengan Teori Modular Le Corbusier tentang menjadikan sebuah modular yang sesuai dengan skala manusia. Secara arah vertikal standar ukuran skala manusia menurut Le Corbusier sebesar 223cm atau 2,2m. Dapat dilihat dari Gambar 3, grid vertikal setiap modul berukuran 2,8 meter, dapat dikatakan bahwa ukuran grid secara vertikal sesuai dengan prinsip modular dari teori Le Corbusier. 


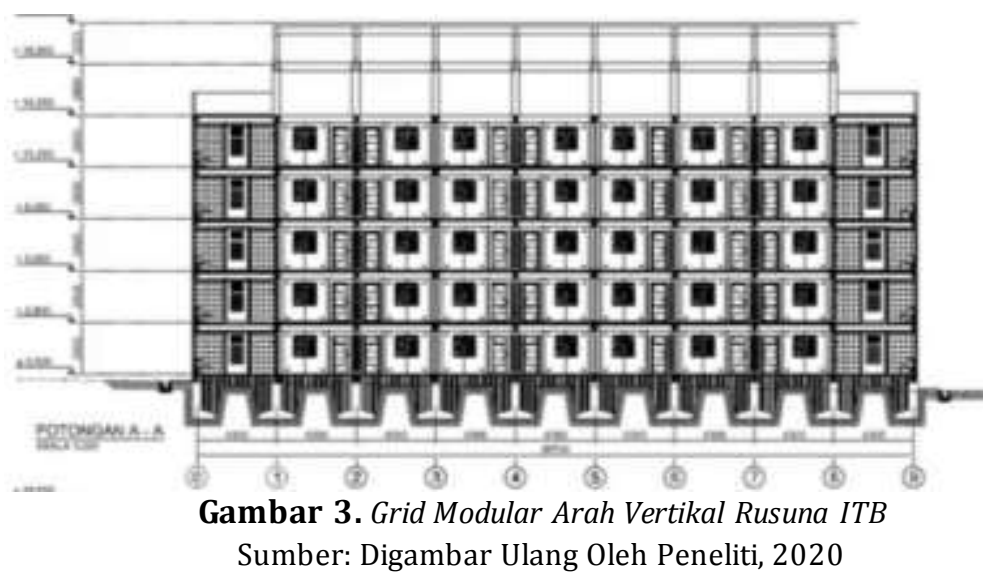

\section{B. Analisis Prinsip Dasar Arsitektur Modular Struktur Prefabrikasi}

Dalam buku Arsitektur prefabrikasi karya Ryan E. Smith, Dasar dari Arsitektur prefabrikasi yaitu mencakup 3 hal (Smith 2011) yaitu :

1. Material Prefabrikasi (Seperti: beton, baja, kayu, petikemas dll)

2. Komponen Modular (Berupa: komponen struktural dan non struktural)

3. Sistem Struktur Prefabrikasi (Seperti: sistem precast, structure steel, MET, PPVC dan sistem modul peti kemas)

\section{a. Material Prefabrikasi}

Material yang digunakan pada Rumah susun ITB Jatinangor ialah material beton bertulang pada struktur bangunannya. Proses fabrikasi disini terdapat pada pencetakan beton bertulang yang kemudian komponen-komponen tersebut dirakit menjadi satu kesatuan. Namun sebelum dicetak proses yang dilakukan ialah penentuan dimensi dan tipe nya, yang kemudian akan disambungkan menggunakan sambungan berupa male and female pada kolom utama dengan material baja, sistem sambungan CL-Con pada balok dengan material beton, dan sistem sambungan pada panel dinding berupa Angkur bermaterial baja.

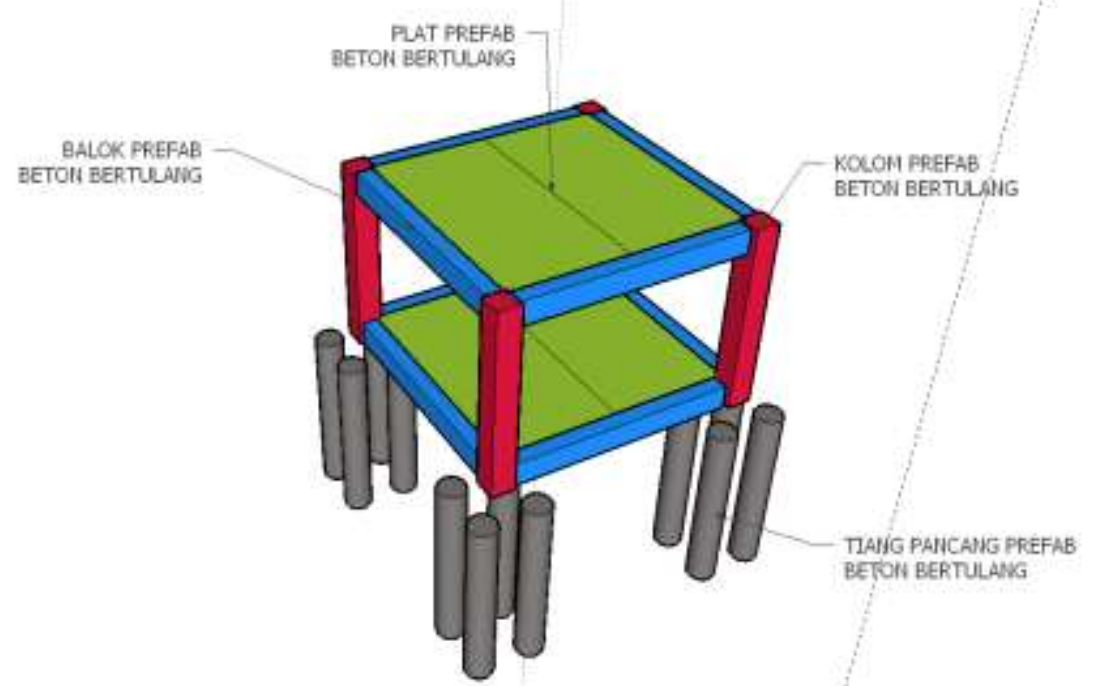

Gambar 4. Grid Modular Arah Horizontal Tipe Double Loaded Rusuna ITB Sumber: Peneliti, 2020

\section{Komponen Modular}

Komponen modular prefabrikasi pada bangunan ini terbagi menjadi 2 jenis, yang pertama ialah komponen struktural dan non struktural. Rumah Susun ITB ini menggunakan material 
beton bertulang, oleh sebab itu komponen komponen baik struktural maupun non struktural berjenis beton bertulang. Detail jenis, dimensi dan lokasi komponen tersebut dapat dilihat pada Tabel 1.

Tabel 1. Komponen Modular

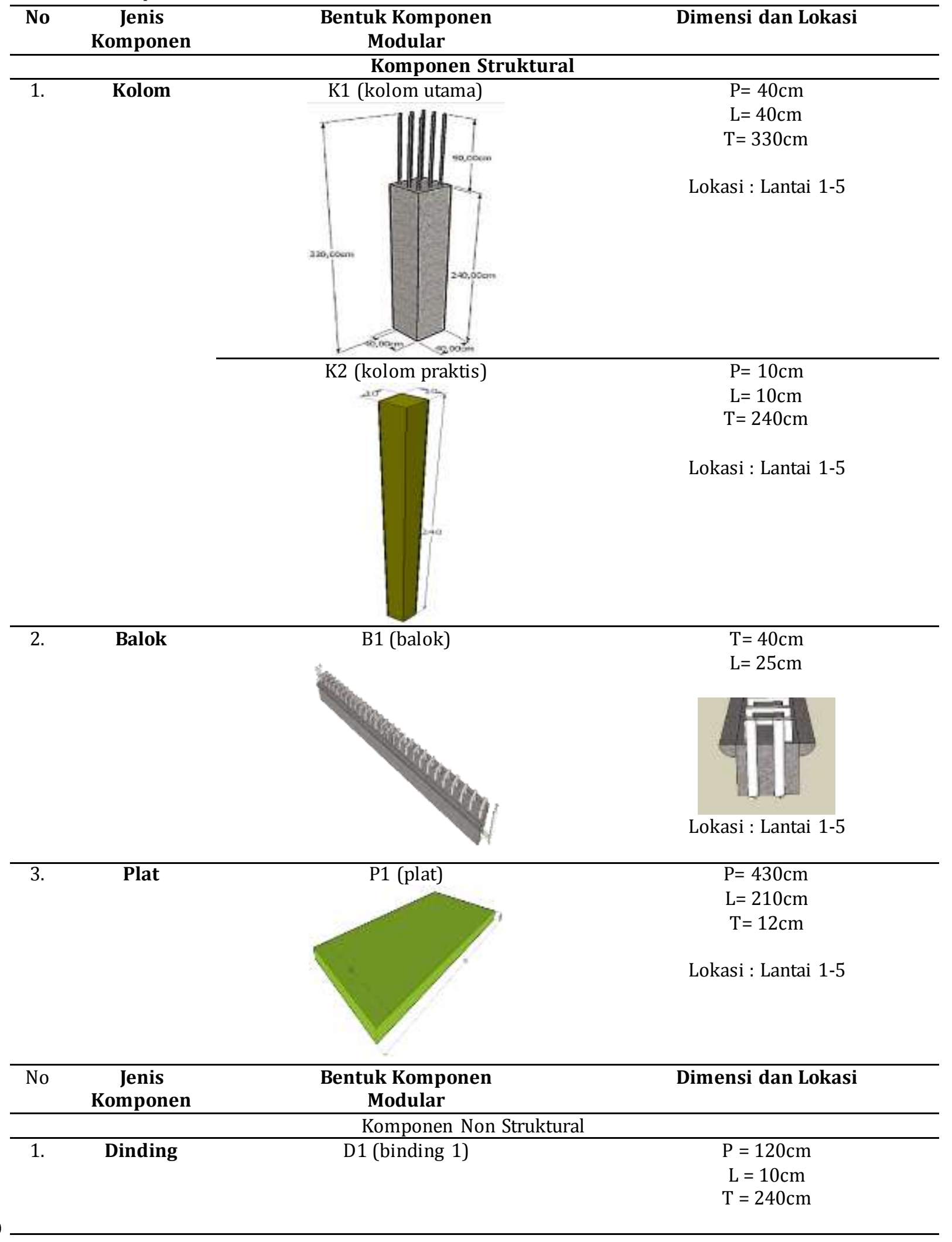




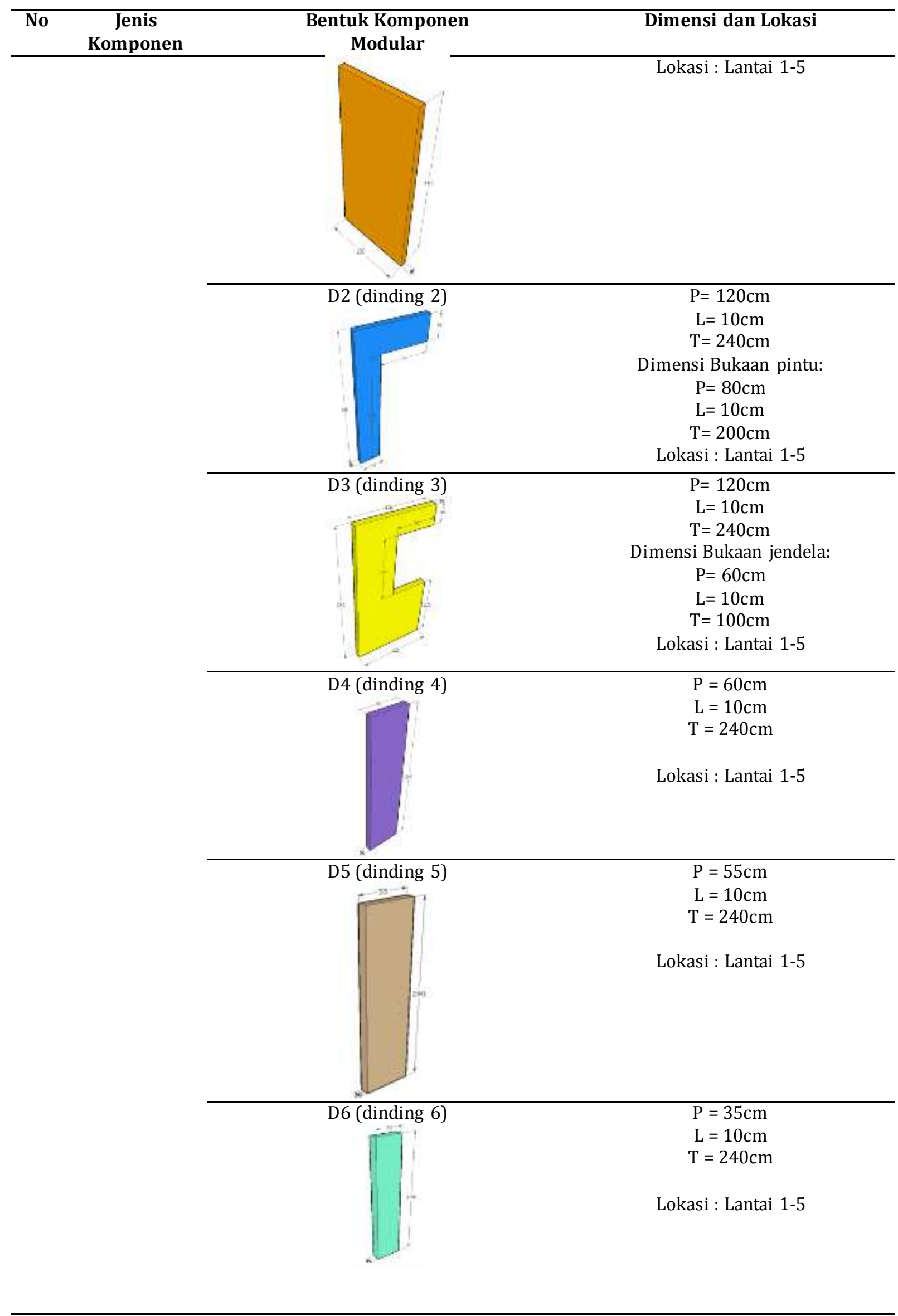




\begin{tabular}{|c|c|c|c|}
\hline No & $\begin{array}{c}\text { Jenis } \\
\text { Komponen }\end{array}$ & $\begin{array}{c}\text { Bentuk Komponen } \\
\text { Modular }\end{array}$ & Dimensi dan Lokasi \\
\hline & & D7 (dinding 7) & $\begin{array}{c}\mathrm{P}=75 \mathrm{~cm} \\
\mathrm{~L}=10 \mathrm{~cm} \\
\mathrm{~T}=240 \mathrm{~cm} \\
\text { Lokasi : Lantai } 1-5\end{array}$ \\
\hline 2 & Tangga & & $\begin{array}{c}\text { Lebar bodres }=110 \times 200 \mathrm{~cm} \\
\text { Lebar anak tangga }=90 \mathrm{~cm} \\
\text { Tinggi anak tangga }=18 \mathrm{~cm} \\
\text { Lokasi : Lantai } 1-5\end{array}$ \\
\hline
\end{tabular}

Sumber: Peneliti, 2020

Pada komponen non struktural memiliki banyak sekali jenis, khususnya pada komponen dinding yang digunakan pada sebuah unit Rumah Susun. 1 unit ruangan menggunaakan 6 jenis komponen dinding yaitu D1,D2,D3,D4,D5 dan D6, peletakan komponen tersebut dapat dilihat pada Gambar 5. Namun komponen-komponen tersebut menjadikan bangunan ini sebagai bangunan modular, karena komponen tersebut hanya dirakit dan disambungkan ditempat. Sebuah ruang yang dihasilkan pada setiap unit Rumah Susun ini tidak terpaku pada ukuran modul ruangnya, dapat dilihat bahwa peletakan komponen dinding melebihi satuan modul ruang.

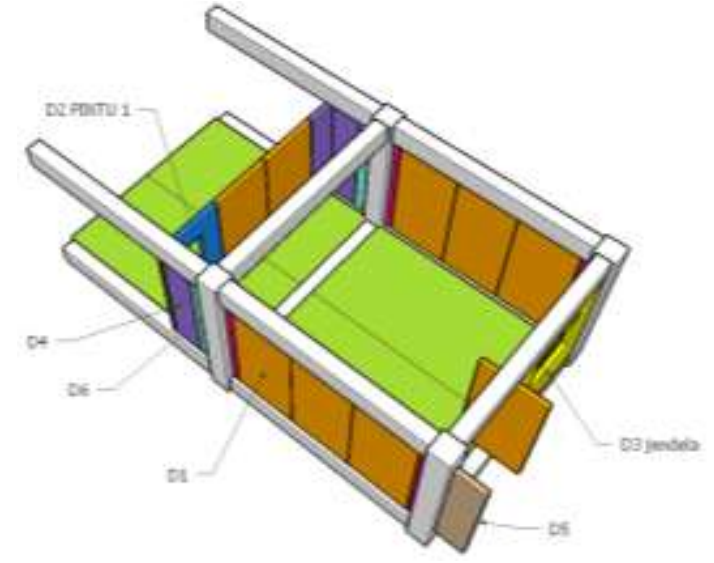

Gambar 5. Komponen Dinding pada 1 Unit Rumah Susun ITB Sumber: Peneliti, 2020

\section{Sistem Struktur Prefabrikasi}

Rumah Susun ITB Jatinangor menggunakan sistem modular precast dengan memakai komponen beton bertulang pada proses pembangunannya. Menurut Sanjaya dan Tobing (2019) sebuah bangunan bisa dikatakan modular dalam pembangunannya apabila proses pembuatannya 60-80\% dilakukan di luar tapak yang kemudian dikirimkan menuju lokasi pembangunan. Rumah Susun ITB ini menggunakan komponen beton precast pada kolom, balok, dinding, plat, tiang pancang dan tangga, maka dapat dikatakan bahwa 95\% komponen pada bangunan ini merupakan komponen modular precast (beton pracetak).

Struktur utama pada bangunan ini ialah pondasi, kolom, blok dan plat, susunan tersebut dapat dilihat pada Gambar 5. Dikarenakan saat proses perencanaan bangunan ini dikategorikan sebagai Rumah Susun modular, maka variasi ukuran pada bangunan ini sangat terbatas, terbukti pada bentang dan tinggi yang digunakan untuk balok dan kolom, hanya 
memiliki 1 ukuran yaitu: bentang balok 4,3m (as to as), dan tinggi kolom 3,3m dengan jarak floor to floor $2,8 \mathrm{~m}$.

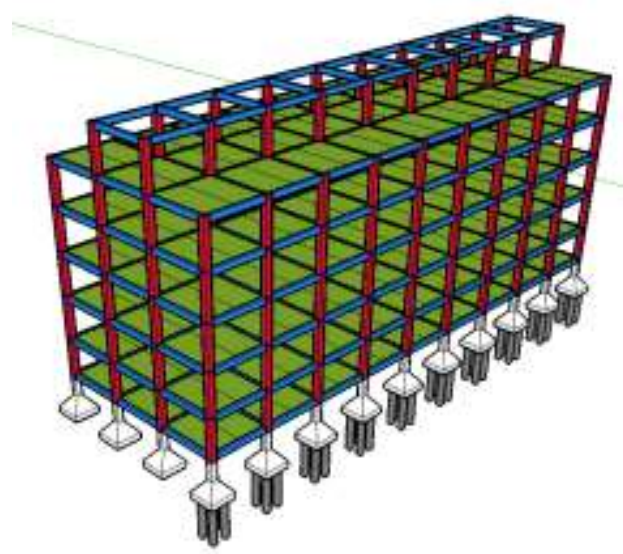

Gambar 6. Skematik Struktur Utama Bangunan Rumah Susun ITB Sumber: Peneliti, 2020

\section{Struktur Bawah (Sub Structure)}

Struktur bawah menggunakan pondasi tiang pancang berbentuk silinder. Pada bagian pondasi secara keseluruhan tidak menggunakan komponen prefabrikasi/komponen modular. Komponen bangunan yang masih menggunakan metode konvensional ialah, pembuatan Pile Cap untuk pondasi namun material nya masih menggunakan beton bertulng, dilakukan secara manual pada site bangunan dapat dilihat pada Gambar $\mathbf{7}$ untuk proses pembuatan.

Titik letak pembuatan pilecap disesuaikan dengan letak kolom utama, dari segi ukuran jarak antar pile cap sama yaitu 4,3 meter sesuai dengan grid modul bangunan, dengan dimensi 180 x $180 \mathrm{~cm}$ tinggi $300 \mathrm{~cm}$, namun untuk bagian pondasi tiang pancang menggunakan struktur modular, sehingga proses yang dilakukan tahapan awal ialah penumbukan tiang pancang lalu pembuatan pile cap beton bertulang secara konvensional. Kesejajaran pada peletakan pondasi dapat terlihat pada Gambar 7. Hal tersebut dipengaruhi oleh grid kolom yang digunakan pada bangunan Rumah Sususn ITB Jatinangor.

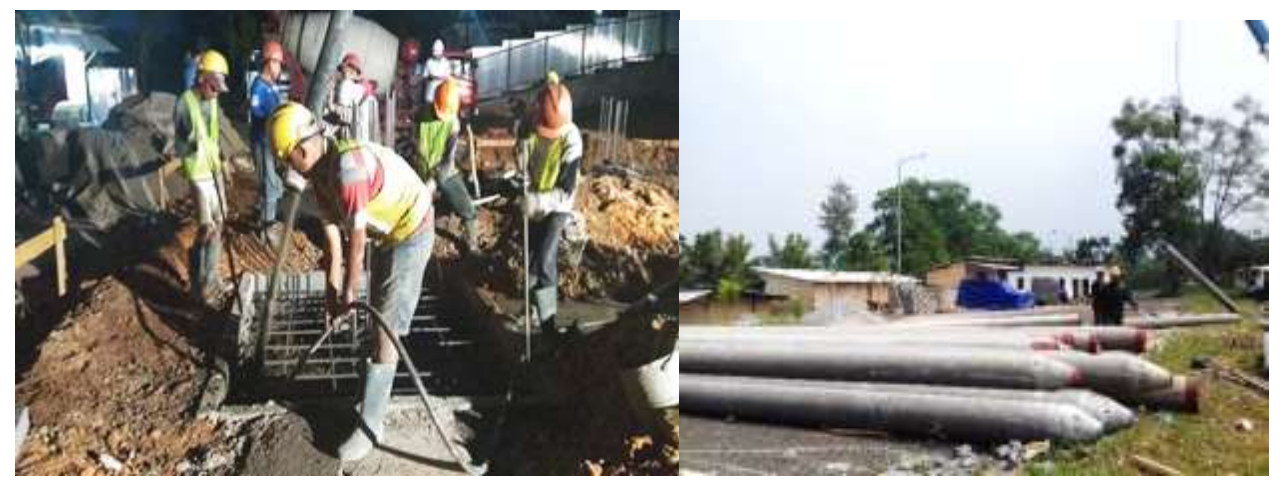

Gambar 7. Proses Pembuatan Pondasi Pada Bagian Pilecap Dengan Metode Konvensional Sumber: itb.ac.id, 2020 

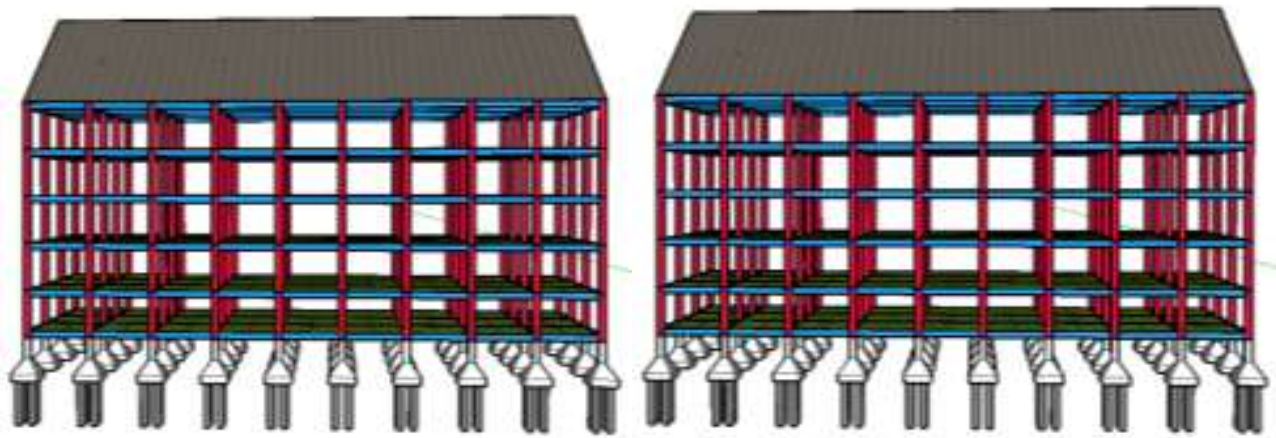

Gambar 8. Skematik Struktur Bawah Bangunan Rumah Susun ITB Jatinangor Sumber: Peneliti, 2020

\section{Struktur Tengah (Middle Structure)}

Kemudian Struktur tengah yang mencakup struktur vertikal berupa Kolom dan Dinding. Serta struktur horizontal berupa Balok dan Plat bangunan. Struktur vertikal ini menerus sampai struktur atap, dimulai dari sambungan kolom-kolom precast ditiap lantainya yang tersambung dengan pondasi, dan kemudian tersambung juga dengan struktur rangka atap. Sambungan pada struktur vertikal ini khususnya kolom, menggunakan sambungan Male and Female system dengan ukuran modul yang dipilih sebesar $40 \mathrm{x} 40 \mathrm{~cm}$ tinggi $330 \mathrm{~cm}$.
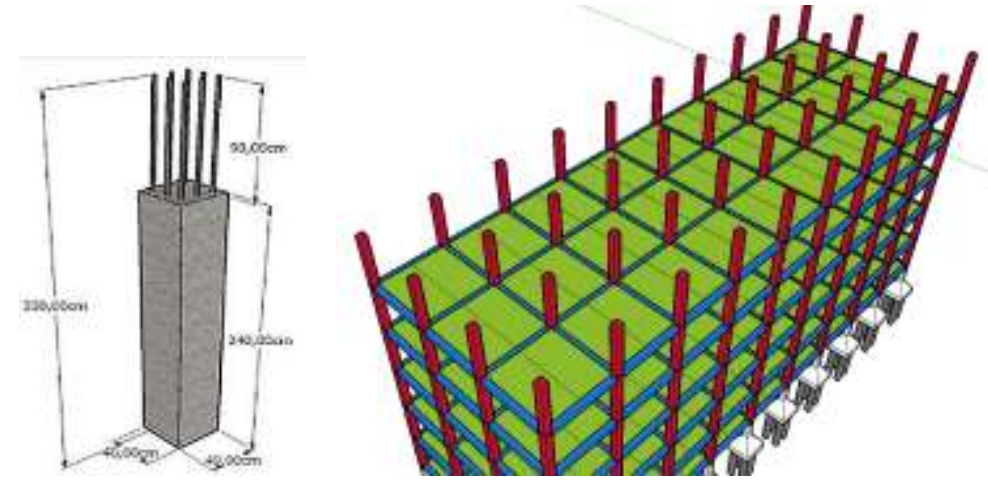

Gambar 9. Detail Struktur Kolom Dan Skematik Struktur Kolom Bangunan Rumah Susun ITB Jatinangor Sumber: Peneliti, 2020

Struktur horizontal yaitu Balok tidak memiliki banyak variasi, bentuk dan ukuran seragam dari lantai dasar hingga lantai atas, hal tersebut memudahkan dalam proses kontruksinya. Sambungan yang digunakan pada balok ini ialah CL-Con hasil dari litbang tahun 2011. Sambungan tersebut merupakan sambungan balok kolom kombinasi dari Dry and Wet Connection.

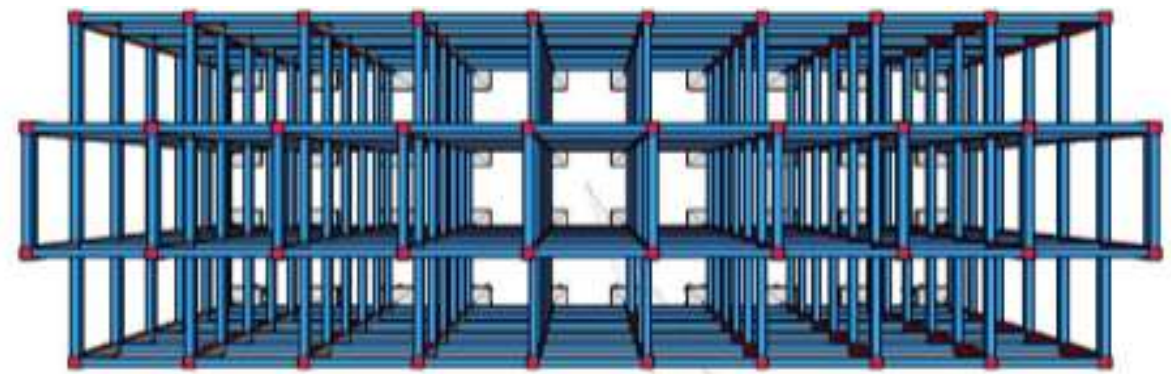

Gambar 10. Skematik struktur balok bangunan rumah susun itb jatinangor Sumber: Peneliti, 2020 


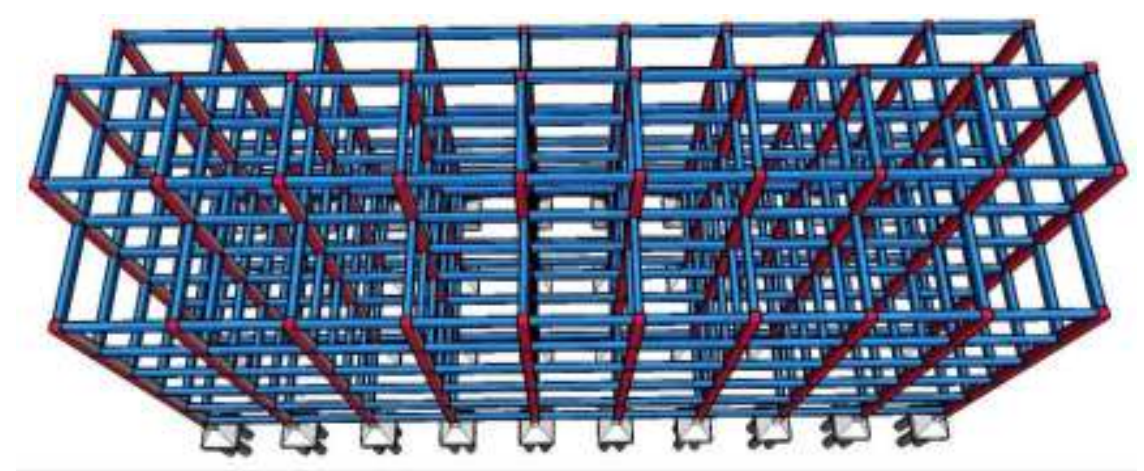

Gambar 11. Skematik Struktur Kolom Bangunan Rumah Susun ITB Jatinangor Sumber: Peneliti, 2020

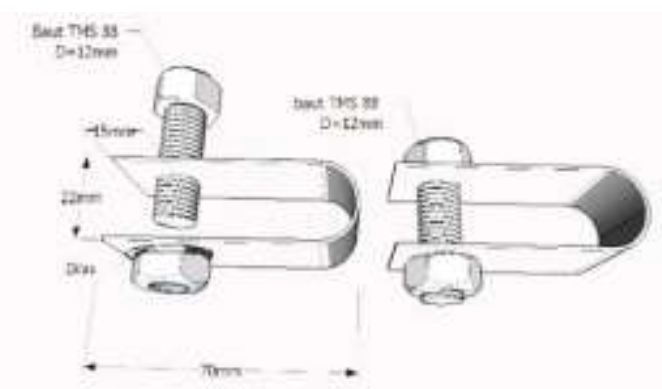

Gambar 12. Detail Sambungan CL-Con Sumber: itb.ac.id, 2020

\section{Struktur Atas}

Pada struktur atas yaitu berupa atap bangunan menggunakan material baja ringan dengan genteng metal, penggunaan material tersebut dikarenakan apabila menggunakan struktur atap modular, beban dan gaya gesek yang diterima bangunan sangat besar, pada struktur atap dibuat menjadi 2 bagian karena, pada modul tengah ruangan dijadikan sebagai tempat toren air, sehingga struktur baja ringan terbagi menjadi 2 sisi yang terikat dengan kolom ruangan toren air, penjelasan tersebut dapat dilihat pada Gambar 13.

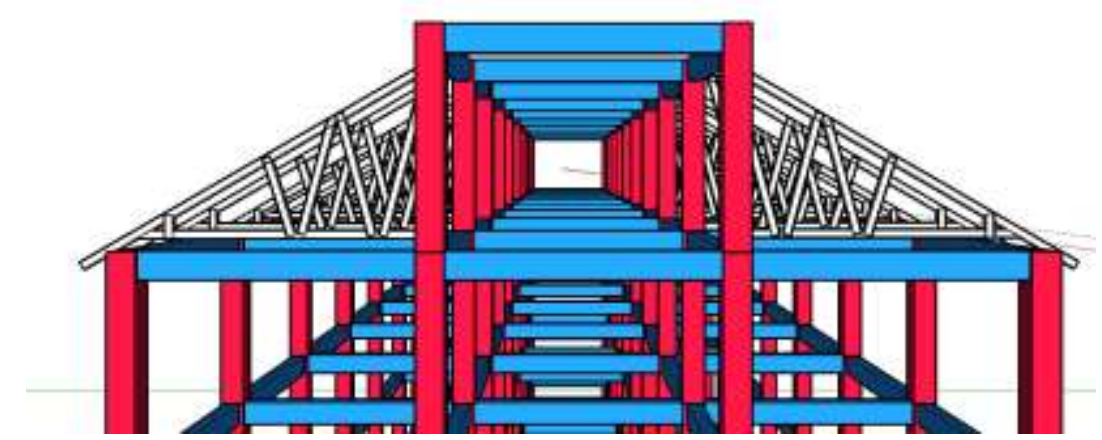

Gambar 13. Skematik Struktur Rangka Atap Bangunan Rumah Susun ITB Jatinangor Sumber: Peneliti, 2020

Hal tersebut akan memudahkan dalam pemeliharaan struktur atap, karena setiap bagian mudah dijangkau dan juga untuk menuju lantai atap telah disediakan sebuah tangga yang menerus hingga lantai dasar. 


\section{Non Struktural Prefabrikasi}

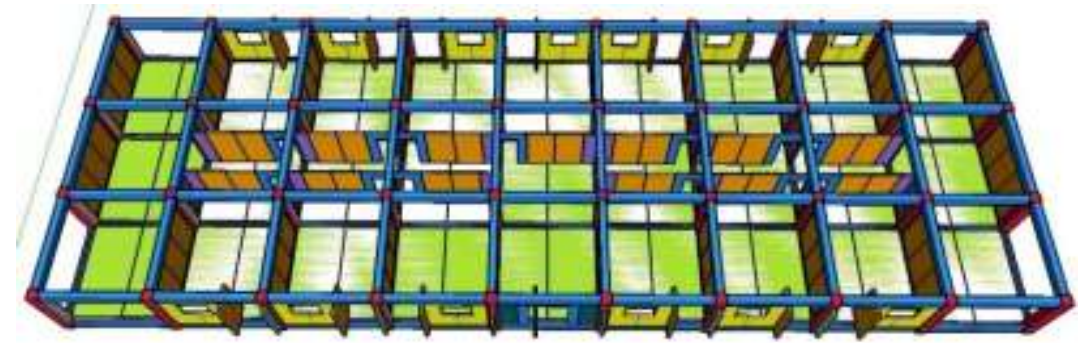

Gambar 14. Penempatan Dinding Bangunan yang Dibuat Dengan Metode Konvensional Sumber: Peneliti, 2020

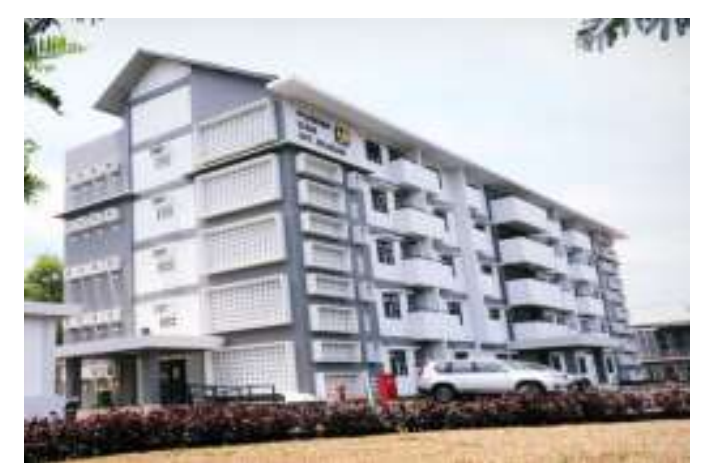

Gambar 15 Detail Dinding Ventilasi Yang Dibuat dengan Metode Konvensional (Non Modular) Sumber: itb.ac.id, 2020

Pada komponen non struktural terdapat panel dinding modular dengan 7 jenis berbeda, namun beberapa area dinding yang diberi tanda pada Gambar 14 tidak bersifat modular, melainkan dikerjakan secara konvensional. Pembuatan dinding tersebut mengunakan komponen bata bertulang yang dikerjakan saat rangka kolom, balok dan plat sudah terpasang. Fungsi area tersebut ialah area ruang Kamar Mandi dan area tangga, dibuat secara manual (metode konvensional), karena detail pada dinding area tersebut dibuat seperti bukaan ventilasi udara, sehingga tidak dibuat modular, detail tersebut dapat dilihat pada fasad bangunan Gambar 15.

\section{KESIMPULAN}

Kesimpulan secara keseluruhan bahwa Rumah susun ITB Jatinangor ini telah menerapkan dan sesuai dengan prinsip serta syarat modular dari Teori Modular Le Corbusier dan 3 Prinsip dasar dari Buku Arsitektur prefabrikasi karya Ryan E. Hal tersebut terbukti pada grid vertikal dan horizontal yang sesuai berupa bentuk modular dengan bentuk standar yaitu grid persegi pada arah horizontal dan grid persegi Panjang pada arah vertikal, dan Modul ruang tersebut telah sesuai dengan skala manusia yang tertulis pada teori Le Corbuseir.

Meskipun pada sistem struktur, bangunan ini secara keseluruhan belum menggunakan komponen prefabrikasi, namun secara garis besar 95\% bangunan ini telah menggunakan modul prefabrikasi antara lain komponen kolom, balok, plat, dinding, tangga dan tiang pancang. Oleh 
karena itu bangunan Rumah susun ITB Jatinangor ini telah sesuai dengan Konsep Arsitektur Modular.

\section{DAFTAR REFERENSI}

Astuti, Susy Budi, Aria Weny Anggraita, M. Husnul Azhar, and Angga Rubianto. 2016. "Persepsi Terhadap Lebar Koridor Utama Pada Apartemen Ditinjau Dari Respon Fisik Pengguna." Jurnal Desain Interior 1 (2): 111. doi:10.12962/j12345678.v1i2.1911.

Mameli, Maddalena. 2016. "Le Corbusier and the American Modulor," 1-13. doi:10.4995/lc2015.2015.984.

Monindra, Aditya. 2016. "Landasan Konseptual Perencanaan dan Perancangan Amusement Park Di Yogyakarta." Universitas Atma Jaya Yogyakarta.

Muryono, Slamet. 2020. "Mendukung Ketahanan Pangan The Potensial Of Sustainable Agricultural Food Mapping To Support Food Security". Slamet Muryono \& Westi Utami. Sekolah Tinggi Pertanaahan Nasional Koresponden E-Mail : Westiutami@stpn.Ac.Id Nomor 41 Tahun 2009 Sebagai Upaya Pemeri,” 201-18.

Prihatanti, Nilla A, and Muhammad Faqih. 2016. "Hunian Vertikal Sewa Dengan Konsep Eko-Modular Arsitektur" 5 (2): 111-15.

Purwanto, Dian. 2016. "Rumah Vertikal Ekologis Di Surakarta dengan Fasilitas Pemberdayaan Ekonomi, Sosial Dan Budaya Masyarakat Berpenghasilan Rendah."

Sanjaya, Wisnu A., and Rumiati R. Tobing. 2019. "Rumah Susun Modular Dengan Pemanfaatan Papan Prafabrikasi CLT, Kasus : Rumah Susun Siwalankerto, Surabaya (Modular Low-Cost Vertical Housing Benefit from Using Prefabricated Cross Laminated Timber Panel)." ARTEKS Jurnal Teknik Arsitektur 3 (2): 199. doi:10.30822/artk.v3i2.168.

Satria, Ivan, and Rony Sunaryo. 2017. “Rumah Susun Modular Di Surabaya.” Jurnal e Dimensi Arsitektur V (1): 729 36.

Smith, Ryan E. 2011. Prefab Architecture: A Guide to Modular Design and Construction. John Wiley \& Sons, Inc. http://books.google.com/books?hl=en\&amp;lr=\&amp;id=pO CliGMKpzUC\&amp;oi=fnd\&amp;pg=PT 20\&amp ;dq=PREFAB+ARCHITECTURE:+a+guide+to+mo dular+design +and+constructio n\&amp; ots=j0n5GteYZ6\&am p;sig=wUYE0qhNDvy5tN_r6P9WQe79p4U.

Subekti, Bambang, M R Alencia, and R R Rafika. 2016. "Penerapan Sistem Koordinasi Modular Bangunan Pada Desain Hunian Vertikal Apartemen TJ." Jurnal Reka Karsa 4 (1): 1-14. https://media.neliti.com/media/publications /221398-penerapan-sistem -koordinasi-mo dular-pa da.pdf. 